\title{
The external-domestic interplay in democracy promotion: a case study on public administration reform in Croatia
}

\author{
Lisa Groß* and Sonja Grimm* \\ Department of Politics and Public Administration, University of Konstanz, Konstanz, \\ Germany
}

\begin{abstract}
In this contribution we conceptualize the under investigated interplay between external and domestic actors in democracy promotion. We first propose a typology of the instruments and means used both by external and domestic actors to influence reform outputs and then trace these instruments' effects on outcomes, thereby expanding the existing concepts of domestic agency. Although democracy promotion continues to be a rather asymmetric relationship between the "donors" and "receivers" of aid and advice, domestic actors employ a wide array of instruments to manage external demands for reform, including diplomacy, take over, slowdown, modification, resistance, and emancipation. The article draws on a case study of European Union democracy promotion within two reform initiatives in the field of Public Administration Reform (PAR) in Croatia.
\end{abstract}

Keywords: democracy promotion; external domestic interplay; European Union; Croatia; transition

\section{Introduction}

The scholarly literature on democracy promotion and on European integration has identified several external instruments to explain the adaption of domestic actors in transition countries to democratic rule. ${ }^{1}$ Much of the discussion centres on the degree of "effectiveness" of these instruments, which include dialogue, persuasion, socialization, democracy assistance, political or membership conditionality, embargos, sanctions, and trusteeship administrations. ${ }^{2}$ However, the majority of democracy promotion studies has taken an "outside-in" approach focusing on external actors to explain effectiveness (or the lack thereof), reducing the agency of domestic actors to "compliance", "partial compliance", or "non-compliance" with external demands. ${ }^{3}$ According to Leininger, the role of domestic actors and in particular the power struggles between different domestic political players and international actors, as well as power struggles among domestic actors, have largely been neglected. ${ }^{4}$ We agree with this assessment and argue that explanations of the influence

*Corresponding authors. Email: lisa.gross@uni konstanz.de, sonja.grimm@uni konstanz.de 
of democracy promotion cannot yield satisfying results without taking the external domestic interplay within reform policies into account.

In order further to illuminate the "black box" of external-domestic interactions in democracy promotion, we deliberately consider the domestic perspective, investigating the interplay between the external actors that promote democracy and the national governments seeking to democratize their political systems. Thereby, we clarify how the interactions between external and domestic actors in transition take place and how this interplay influences the outputs of democratic reform. To answer these questions, we first conceptualize the interaction between a major external democracy promoter, the European Union (EU), and a national government in a country in transition (here, Croatia), proposing a fine-grained typology of the instruments used by both external and domestic actors. Second, we trace the interplay between external and domestic actors to explain the outputs of externally demanded democratic reforms. In this regard, Croatia in particular represents a paradigmatic case and permits us to systematize the instruments used by both sides. Croatia's bumpy path to democracy allows not only an exploration of conditions supportive of the external-domestic interplay, but also of the obstacles accompanying the largely asymmetric relationship between an external democracy promoter and a domestic receiver of aid and advice.

The contribution proceeds as follows: in the section that follows, the state of the art in democratization and post-conflict transition under external oversight is summarized. The third section justifies the selection of Croatia and its Public Administration Reform (PAR; in Croatian Reforma javne uprave) as a case study. Key aspects and actors of PAR in Croatia are introduced. The fourth section discusses our methodological approach. The fifth section presents a new typology of the instruments used by external and domestic actors in their interplay. This is employed in the penultimate section to conduct a fine-grained process-tracing of the actors' interactions during the reform process. A concluding section summarizes the results of the analysis.

\section{The state of the art}

Three branches of research offer first insights for conceptualizing the interplay between domestic and external actors: democracy promotion studies, the literature on European integration and compliance, and studies on international norm pro motion. The democracy promotion literature analyses various forms of democracy-promoting instruments and influential external and domestic factors for their success, whereas the literature on European integration focuses on the external and domestic conditions of EU rule and norm transfer to EU member states and (potential) candidates for membership. The International Relations (IR) literature on norm promotion discusses domestic reactions to international norm-promotion activities. Taken together, these three research fields offer a starting point for the examination of the external-domestic interplay in democracy promotion. Our review will, however, also reveal the research gaps that need to be addressed in all three. 


\section{Democracy promotion: actors and instruments}

Actor-centred transition studies have long pointed to the importance of domestic actors in democratization. Transition researchers identify the behaviour of domestic actors as crucial for democratic transitions and understand transition results as an outcome of the iterated strategic decision-making of the politically relevant actors while keeping in mind that actors are constrained by structural conditions. ${ }^{5}$ Recent publications on democracy promotion address the contribution of external actors to democratization. ${ }^{6}$ Discussions centre on various types of democracy promotion, such as the international support of democratic elections, the drafting of democratic constitutions, reforms of the judiciary and state bureaucracy, the support of civil society projects, and the encouragement of a free and plural media environment. ${ }^{7}$ Thereby, the literature distinguishes between different external instruments of democracy promotion, such as political dialogue, democracy assistance, political conditionality, embargos, sanctions, and trusteeship administrations. $^{8}$ Although some contributions have raised the fact that democratization requires domestic support, there has been no systematic integration of an "inside-out" perspective in terms of an exploration of how domestic actors perceive and handle external reform demands. ${ }^{9}$

\section{European integration: conditions for successful democracy promotion}

Studies on European integration take a special look at the EU as a key external player in democracy promotion with respect to how it rewards reform progress with financial assistance, technical expertise, and a membership perspective. For (potential) EU members, the EU uses instruments including conditional incentives, normative pressure, and persuasion. Policy and membership conditionality, which refers to how the EU sets rules that must be fulfilled in order for a country to receive rewards, is seen as its most powerful instrument to induce democratic change. ${ }^{10}$ These studies also discuss domestic factors that can mitigate the "effectiveness" of external instruments in the form of modification costs, such as the number of veto players, societal mobilization for or against reform, administrative capacity, and the framing of reforms that touch issues of national identity. ${ }^{11}$ However, domestic actors have been reduced to a rather one-dimensional role in this process: Either they comply with EU reform demands, or they do not. ${ }^{12}$ Scarcely any study in this field conceptualizes domestic actors as capable and willing to deal with, transform, or resist external reform demands, or as competent to take action independently. ${ }^{13}$ We argue that compliance or non-compliance with EU demands is not a one-way street, but rather a two-way interaction in which domestic actors are equally able to challenge external preferences and demands.

\section{International norm promotion: mapping domestic agency}

The IR literature on international norm promotion does conceive of democracy promotion as an interactive process between external and domestic actors. Transnational norm entrepreneurs link up with local civil society organizations to 
pressurize authoritarian governments into concessions and compliance with human rights norms. ${ }^{14}$ This branch of the literature offers a point of departure for the consideration of domestic agency and the external-domestic interaction in democracy promotion, allowing the differentiation of three categories of domestic agency in international norm promotion: compliance, adjustment, and resistance. Compli ance describes a state of conformity or identity between an actor's behaviour and a specific rule; this involves the adoption and implementation of the law, rule, or procedure in question. ${ }^{15}$ We prefer, however, the term take over instead of compliance, as it underscores the agency of domestic actors in taking over laws, rules, or procedures, but does not preclude anything about the domestic actors' motivations, attitudes, or stages of learning. Adjustment describes the changes domestic actors make in externally demanded laws, rules, or procedures in order to make them more suitable to the context of the society in transition. In the research on norm diffusion, similar concepts are "filtering" and "localization". ${ }^{16}$ We prefer to speak in terms of modification, again to better highlight domestic agency in the process of transferring and modifying externally promoted norms into domestic contexts. In the literature, resistance tends to be connected with ostensibly undemocratic political elites who keep a tight grip on state power and oppose the opening of the political or economic sphere. ${ }^{17}$ However, this interpretation creates a rather negative connotation for legitimate critical attitudes towards challenging largely context-insensitive external reform demands that do not resonate with local needs or the everyday life of the citizens affected. ${ }^{18}$ Therefore, we restrict the use of the label "resistance" to domestic behaviour that simply declines external reform proposals in whole or in part.

In addition to these three forms of domestic behaviour derived from the norm promotion literature, we assume that domestic actors are also involved in constant negotiations with external actors regarding the concrete contents, scale, and scope of reform - a departure from the rather passive role that especially the first two strands of literature discussed above have assigned to domestic actors. Furthermore, domestic actors might go beyond externally induced reform demands in developing their own reform projects, thereby emancipating themselves from external actors and their preferences. To summarize, there is a need to further specify and conceptually systematize the forms of domestic agency at work in the process of external-domestic interplay. In the remainder of this contribution, we explore the full set of instruments used by both sides in the external-domestic interplay during democracy promotion, and we outline the consequences of this interplay for reform outputs.

\section{Public administration reform in Croatia}

Croatia's transition offers a perfect opportunity to study the interaction between external and domestic actors in post-conflict democracy promotion. Croatia's transition can be considered a "paradigmatic case", ${ }^{19}$ as Croatia's experience is highly representative of the extraordinarily intense efforts of the international community 
to overcome the consequences of violent state dissolution and civil war through state-building and democracy promotion. The EU in particular has assisted postconflict democratization with diplomatic initiatives, the provision of aid, conditionality, and the supervision of state-building. ${ }^{20}$ Studying the interplay between the EU and the Croatian government thus captures the full range of external instruments used in post-conflict democracy promotion. Similarly, the Croatian political elite showed great willingness to implement democratic reforms, while at the same time remaining critical of what they viewed as "too much" external interference in domestic state affairs. We expect this variance in attitudes to be reflected in the respective behaviours of domestic actors in policy formulation and implementation.

Croatia's transition also represents a case of "maximum variation", ${ }^{21}$ because it illustrates both successes and failures in democratization under external oversight. On the one hand, Croatia has made considerable progress in democratization, which has been rewarded with prospective accession to the EU in 2013. On the other hand, experts on the region continue to criticize the fact that Croatian political elites have failed to adequately accept democratic rules and norms, and EU progress reports criticize the Croatian government for its slow progress in the implementation of reforms and in the fight against corruption. ${ }^{22}$ Croatia's transition thus allows us to trace external-domestic interaction processes in both successful and failed reform endeavours. We take public administration reform (PAR) as an example, identifying two PAR initiatives with different reform outputs as "within-units" 23 of case analysis. We expect that variation in the external-domestic interplay will explain the mixed reform outputs, which are typical of transition under external oversight in developing countries across the world.

\section{EU engagement in Croatia's PAR}

Serious reform efforts in the Croatian public administration started in 2000, when a centre-left coalition government under Prime Minister Ivica Račan gained office and when the EU became more active in the Western Balkans and clearly committed itself to promoting democracy in the region. ${ }^{24}$ The overall goal of external actors in engaging in PAR is to optimize the structures and mechanisms of administrative state bodies based on democratic principles. Reliable, open, transparent, and citizen-oriented public administration is considered a prerequisite of a good business environment and a better living standard of all citizens..$^{25}$ Common standards of public administration shared by EU member states are laid down in the "European Administrative Space" (EAS) policy and EU Best Practices. The EAS defines four main administrative principles: (1) the rule of law, defined as "legal certainty and predictability of administrative actions and decisions", (2) openness and transparency, "the scrutiny of administrative processes and outcomes and its consistency with pre-established rules", (3) the accountability "of public administration to other administrative, legislative or judicial authorities [to ensure] compliance with the rule of law", and (4) efficiency "in the use of 
public resources and effectiveness in enforcing the policy-goals established in legislation". ${ }^{26}$ These principles have guided the reform of the Croatian administration.

The EU uses instruments such as diplomacy, democracy assistance, and (soft) conditionality in all PAR reform initiatives. Democracy assistance for PAR has been provided through two framework programmes: the "Community Assistance for Reconstruction, Development and Stabilization" (CARDS) and subsequently the "Instrument of Pre-Accession Assistance" (IPA). ${ }^{27}$ Conditionality is not applied in a strict sense, because PAR is not part of the EU membership conditionality framework: it does not represent a chapter in accession negotiations. However, PAR is included among the soft political criteria that are regularly discussed in EU progress reports.

\section{Comparing two PAR reform initiatives: GAPA and CSSA}

Based on the output of reform (namely, whether the reform initiative has resulted in policy adoption by the Croatian parliament or not), we selected two reform initiatives within PAR for study: the General Administrative Procedures Act (GAPA; in Croatian: Zakon o općem upravnom postupku) and the Civil Servants Salary Act (CSSA; in Croatian: Zakon o plaćama državnih službenika). At the end of 2011, the cut-off point for this study, a version of the GAPA had been adopted in parliament ("success"); in contrast, the CSSA was still being negotiated between the government and third-party actors ("no success"). ${ }^{28}$

The reforms involved in the GAPA have the goal of simplifying and speeding up administrative decision-making structures to improve services for both citizens and businesses; while the CSSA is an attempt to unify the wage system for civil servants and render it more competitive. ${ }^{29}$ In both cases, the Croatian Ministry of Administration (MoA; in Croatian: Ministarstvo uprave) is responsible for the preparation and implementation of reforms, which began in 2003. The two PAR reform initiatives are similar with regard to external factors. The sets of requirements for the measures are only loosely defined, based on EAS principles and EU Best Practices; ${ }^{30}$ the credibility of the reward (in the form of EU membership) is high. The process of EU democracy promotion has been shaped in both cases by diplomacy, democracy assistance, and (soft) conditionality and the two reform initiatives differ only slightly in terms of the financial resources invested. ${ }^{31}$ With respect to domestic factors, the GAPA and CSSA differ concerning the number of potential veto players involved and the potential for societal mobilization: The GAPA involved the MoA, the cabinet, and (at later stages) the parliament in negotiations, whereas the CSSA additionally included the Ministry of Finance, other line ministries, and various Croatian trade unions. The administrative capacity involved has been similar, as the MoA was the main actor in both processes, and neither reform was connected to issues regarded as problematic in the literature, such as violent conflict or national identity. 


\section{Methodological approach}

Our study implements qualitative approaches of the comparative case study method to conceptualize and analyse the external-domestic interplay. ${ }^{32}$ Process-tracing of individual reform initiatives serves to disentangle variation in the external-domestic interplay during reform and to explain the different outputs. A classical policy cycle is employed as an analytical frame for the process-tracing.

\section{Data collection and analysis}

Semi-structured expert interviews were the primary instrument of data collection, complemented by document analysis. ${ }^{33}$ The aim of the interviews was to gain detailed knowledge about the process of interaction between external and domestic actors in order to facilitate the identification of patterns of interaction within specific reform initiatives. The relative openness of the semi-structured interviews allowed us to discover previously unknown external and domestic instruments in the external-domestic interplay of democracy promotion.

Interview partners were selected to include those interaction experts most closely involved in the administration reforms, especially individuals at the interface between external and domestic actors. ${ }^{34}$ The domestic interview partners were officials in the MoA (at different levels in the hierarchy), the Chief Negotiators' Office, national agencies managing EU assistance, and trade unions. External actors included members of the EU delegation in Croatia, team members for EU financial assistance projects, and a few other donors in the field. In total, 30 interviews were held between August and November 2011. Depending on the interviewee, the interviews were held either in Croatian or in English.

Interview analysis proceeded inductively; actions mentioned by each interview partner were clustered to establish the instruments and specific means of interacting with the external or domestic counterpart. Process-tracing of specific instruments was then employed to identify patterns of external-domestic interactions and to explain reform outputs. ${ }^{35}$

\section{The policy cycle as an analytical frame}

In the analysis of EU norm-promotion activities, scholars distinguish several steps of norm change in the states undergoing democracy promotion. ${ }^{36}$ In developing these approaches further, we propose to bring the analysis of EU norm promotion conceptually closer to the actual policy-making process in the domestic-policy arena by using the concept of the policy cycle (see Figure 1). ${ }^{37}$ The policy cycle describes policy-making as a sequence of steps related to decisions and actions concerning a specific policy. ${ }^{38}$ The model differentiates between the stages of agenda-setting, policy formulation, policy adoption, policy implementation, and evaluation. ${ }^{39}$ In democracy promotion, external actors de facto participate in all stages of policy-making, with policy adoption in domestic parliaments being the only stage in which external actors are formally excluded. Thus, the 


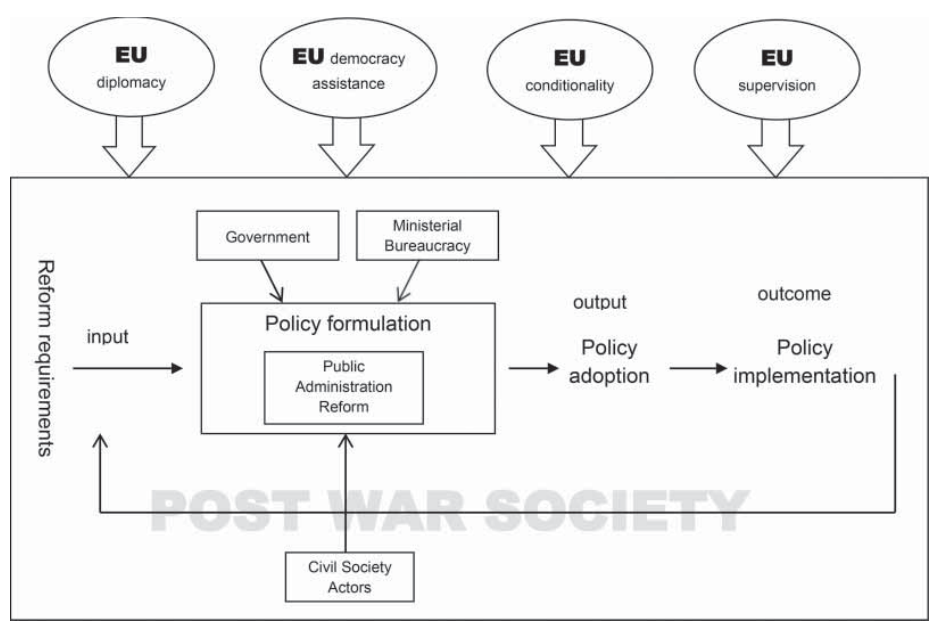

Figure 1. The policy cycle as an analytical frame.

Source: Authors' compilation.

external-domestic interplay can be observed throughout the entire process, making the policy cycle a useful tool to separate the different phases of interaction between democracy promoters and national actors. Our analysis of external-domestic interactions concentrates (due to limited space) on the first three steps of the policy cycle of the GAPA and CSSA: agenda-setting, policy formulation, and policy adoption.

\section{Conceptualizing the external-domestic interplay}

The specific instruments used by the two sides in the external-domestic interplay of democracy promotion will be presented now in greater detail. We go beyond the existing literature in additionally specifying the means used in the implementation of these instruments. The term means refers to specific actions that are undertaken by individual actors during the reform process and that allow a follow-up action from the counterpart, creating an interaction. On the external side, we follow the general literature and differentiate between the instruments of diplomacy, democ racy assistance, conditionality, and supervision. ${ }^{40}$ The external instruments differ according to the general level of leverage that external actors are able to mobilize to influence the democratic reform process, with diplomacy having the least leverage and supervision the most. On the domestic side, based on the literature (see Section 2) and on our explorative study, we identify six instruments that characterize domestic actors' behaviour in the external-domestic interplay: diplomacy, take over, slowdown, modification, resistance, and emancipation. Here, a ranking of instruments is more difficult, as they describe different options of reform-supportive or reform-critical behaviour. In the following analysis, external and domestic instruments are presented together with their specific means. 


\section{External instruments}

In theory, the various instruments used by external actors to promote democratic reform emphasize analytically distinct reasoning. In practice, however, instruments are used complementarily and are not necessarily mutually exclusive (for an overview, see Table 1).

Diplomacy describes the practice of negotiation between representatives of external and domestic actors. Diplomacy is primarily based on arguments, less on material incentives, and can include alliance-building with other actors. ${ }^{41}$ Democracy assistance refers to the provision of financial resources or political expertise to support institution-building and actors' empowerment. ${ }^{42}$ Democracy assistance functions top-down for political institution-building and capacity-building; is transmitted bottom-up with respect to the development civil society and free press. ${ }^{43}$ Conditionality is a bargaining strategy of reinforcement by reward; the EU uses conditionality when it provides the incentive of EU membership to encourage a target government to comply with its conditions. ${ }^{44}$ The EU rewards target governments for alignment with its conditions and withholds the reward for non-compliance. Supervision is defined as the (temporary) take-over of decisionmaking - and implementing capacity by an external actor. This strategy was developed in particular for the transitional arrangements in Bosnia and Herzegovina (the High Representative/Special Representative of the EU) and in Kosovo (the United Nations Interim Administration in Kosovo/International Civilian Representative), ${ }^{45}$ but does not apply in the case of Croatia. Table 1 presents an overview of these instruments, together with the various means that can be used by external actors to direct the reform process.

\section{Domestic instruments}

The attitude of domestic actors towards external demands for democratic reforms can range from very supportive to very critical. Even when they are critical, the governments and state officials of democratizing countries do not necessarily oppose the fundamental ideas that lie behind an external reform initiative - such as improving transparency, accountability, or service-orientation to citizens but they might substantially disagree with the scope and scale of desired reforms, with the necessary degree of local third-party participation in policymaking, or with the implementation of the reform. In the course of our investigation, we found six domestic instruments that were employed to deal with external involvement in democratization: diplomacy, take over, slowdown, modification, resistance, and emancipation (for an overview, see Table 2).

Diplomacy refers to the practice of negotiating with external actors over the direction of reform or specific details of a policy draft and its implementation. Arguments and bargaining strategies are used to strengthen the domestic position and to convince the international counterpart about a compromise that is acceptable to both sides. Take over is a practice in which domestic actors follow specific external demands in the process of policy-making, taking over the goals and practices of 
Table 1. Instruments of external actors.

\begin{tabular}{|c|c|c|}
\hline Instrument & Means & Description of means \\
\hline \multirow[t]{7}{*}{ Diplomacy } & Discuss and argue & Discuss and argue over reforms to find a compromise between various interests \\
\hline & Consult stakeholders & Consult stakeholders regarding their opinions on reform \\
\hline & $\begin{array}{l}\text { Ally with stakeholders/third } \\
\text { parties }\end{array}$ & $\begin{array}{l}\text { Build alliances with other actors with similar interests (domestic or external) via information sharing, } \\
\text { informal meetings, coordination mechanisms }\end{array}$ \\
\hline & Lobby & Lobby top level politicians to push reform \\
\hline & Issue "recommendations" & Issue recommendations to comment on reform \\
\hline & Issue communiqués & Issue communiqués to comment on reform \\
\hline & Modify/drop demand & Modify or drop reform demands in favour of domestic actors' interests \\
\hline \multirow{10}{*}{$\begin{array}{l}\text { Democracy } \\
\text { assistance }\end{array}$} & Empower & Transfer responsibility in the reform process to domestic actors \\
\hline & "Propose" assistance & Propose specific reform projects and offer financial assistance \\
\hline & Set pre conditions & Set pre conditions for financial assistance connected to other reforms \\
\hline & Control assistance & $\begin{array}{l}\text { Control the project cycle of assistance: writing, commenting, rejecting project proposals, tendering, } \\
\text { contracting, procurement, management, monitoring }\end{array}$ \\
\hline & Advise on policy & Participate in policy formulation, commenting on content or strategy of reform \\
\hline & Draft policy paper & Participate in policy formulation by drafting policy or strategy papers \\
\hline & Draft law & Participate in policy formulation by drafting laws \\
\hline & Advice on implementation & Participate in policy implementation, commenting on goals, strategy, or the implementation of reform \\
\hline & Re allocate/withdraw & (Threat to) withdraw or re allocate money \\
\hline & Modify/drop demand & Modify or drop reform demands in favour of domestic actors' interests \\
\hline \multirow[t]{5}{*}{ Conditionality } & Set soft criteria & Include reform demands as soft political criteria in progress report \\
\hline & Set benchmarks & Include reform demands as a benchmark in EU accession negotiations \\
\hline & Monitor & Monitor reform progress of political criteria or benchmarks \\
\hline & $\begin{array}{l}\text { Threat to deny EU } \\
\text { membership }\end{array}$ & State clearly that there is no room to negotiate on EU demands \\
\hline & Modify or drop demand & Modify or drop benchmarks or soft political criteria in favour of domestic actors' interests \\
\hline \multirow[t]{4}{*}{ Supervision } & Execute veto power & $\begin{array}{l}\text { Propose reform projects and execute a veto if a domestic initiative runs contrary to external } \\
\text { requirements }\end{array}$ \\
\hline & Draft laws & Take the lead in policy formulation by drafting laws \\
\hline & Adopt laws & Take the lead in policy making by adopting laws \\
\hline & Implement laws & Take the lead in policy making by implementing laws \\
\hline
\end{tabular}

Source: Authors' compilation. 
the external actors. This term describes a process of acceptance on the domestic side of the ideas and practices of external actors. Slowdown refers to actions of domestic actors that result in the deceleration of initiated reforms, such as the withdrawal of administrative resources from the policy, inability to reach an agreement, and postponement of decision-making in parliament. In modification, domestic actors selectively change external reform proposals. Modification implies the introduction of changes to external reform drafts or the reinterpretation of already adopted laws in a way that is considered more appropriate to the given context. Resistance describes the rejection of external reform demands. Resistance might be targeted against the external proposals of a specific reform initiative, complete reform drafts, parts of reform drafts, or recommendations to proceed in the implementation of a new policy. Emancipation refers to the development of reform goals and strategies independent of external demands. As the result of an increasing awareness of the "misfit" between externally demanded reforms and conditions on the ground, or due to growing self-esteem, domestic actors may begin to search for their own solutions to problems, thereby possibly disregarding external reform proposals.

\section{Patterns of the external-domestic interplay}

In order to show how the external-domestic interplay functions in practice and the kinds of patterns that can evolve, two selected reform initiatives, the GAPA and the CSSA, are now studied in greater detail. Each reform initiative is briefly introduced, the phases of the external-domestic interplay in the policy cycle presented, and the instruments employed by the two sides to promote their political interests discussed. Finally, the dynamics of the interplay in the two reform initiatives are compared. References to interview partners have been anonymized (the letter " $\mathrm{D}$ " indicates an interviewee on the domestic side; "E" an interviewee on the external side) and consecutively numbered.

\section{External-domestic interplay with the GAPA}

With a reform of GAPA, external actors sought to enhance the legal certainty, transparency, and effectiveness of the Croatian administration by introducing e-administration, reducing the number of regulations by half, and by decreasing the myriad "special procedures" that required specific administrative decisions to be amended by the parliament. ${ }^{46}$ Reforming the GAPA meant changing the backbone of the Croatian administration, which had been functioning on this legal basis since the 1950s under Yugoslav-socialist rule. ${ }^{47}$

The main external actor promoting the reform of the GAPA was the EU, who regularly discussed the progress of this reform in accession negotiations and provided financial assistance with CARDS 2003 and IPA 2008 projects. Complementary assistance was offered by the Danish bilateral assistance programme, the US Agency for International Aid (USAID), and the "Support for Improvement 
Table 2. Instruments of domestic actors.

\begin{tabular}{|c|c|c|}
\hline Instrument & Means & Description of means \\
\hline \multirow[t]{3}{*}{ Diplomacy } & Discuss and argue & $\begin{array}{l}\text { Discuss and argue to find a compromise } \\
\text { between various interests regarding a reform }\end{array}$ \\
\hline & Consult stakeholders & $\begin{array}{l}\text { Consult stakeholders regarding their opinions } \\
\text { on reform }\end{array}$ \\
\hline & $\begin{array}{l}\text { Ally with stakeholders/ } \\
\text { third parties }\end{array}$ & $\begin{array}{l}\text { Build alliances with other actors with similar } \\
\text { interests (domestic or external) via } \\
\text { information sharing, informal meetings, } \\
\text { coordination mechanisms }\end{array}$ \\
\hline \multirow[t]{3}{*}{ Take over } & Agree to EU goals & $\begin{array}{l}\text { Listen to and be persuaded by the ideas of } \\
\text { external actors }\end{array}$ \\
\hline & Agree to EU demands & $\begin{array}{l}\text { Agree to EU demands regarding reform process } \\
\text { (accepting assistance, establishing working } \\
\text { groups, and so on), often for the incentive of } \\
\text { receiving EU membership or financial } \\
\text { assistance }\end{array}$ \\
\hline & Use EU tools & $\begin{array}{l}\text { Take over policy making tools used by EU, } \\
\text { such as project management or formulating } \\
\text { strategies }\end{array}$ \\
\hline \multirow[t]{8}{*}{ Slowdown } & Pay "lip service" & $\begin{array}{l}\text { Agree to EU reform demands or offers of EU } \\
\text { financial assistance "with head, but not with } \\
\text { heart" }\end{array}$ \\
\hline & Assign low priority & $\begin{array}{l}\text { Assign low priority to EU demanded reforms in } \\
\text { day to day work }\end{array}$ \\
\hline & Assign low resources & $\begin{array}{l}\text { Provide insufficient financial or human } \\
\text { resources for the formulation or } \\
\text { implementation of reforms }\end{array}$ \\
\hline & Find no agreement & $\begin{array}{l}\text { Find no agreement between different } \\
\text { stakeholders in the reform }\end{array}$ \\
\hline & Postpone decision & $\begin{array}{l}\text { Postpone decision by parliament to adopt the } \\
\text { new reform }\end{array}$ \\
\hline & Delay implementation & $\begin{array}{l}\text { Delay steps necessary for the implementation of } \\
\text { an adopted reform }\end{array}$ \\
\hline & $\begin{array}{l}\text { Delegate responsibility } \\
\text { ineffectively }\end{array}$ & $\begin{array}{l}\text { Delegate responsibility to people who are } \\
\text { incompetent or hold low positions in the } \\
\text { governmental hierarchy }\end{array}$ \\
\hline & $\begin{array}{l}\text { Re organize working } \\
\text { groups }\end{array}$ & $\begin{array}{l}\text { Abolish working groups that were established } \\
\text { to formulate, monitor, or evaluate reforms }\end{array}$ \\
\hline \multirow[t]{4}{*}{ Modification } & Adopt and ignore & Partially ignore laws during implementation \\
\hline & Adopt and re interpret & $\begin{array}{l}\text { Partially change the interpretation of laws } \\
\text { during implementation }\end{array}$ \\
\hline & Change reform draft & $\begin{array}{l}\text { Add, delete, or select parts of an externally } \\
\text { proposed reform draft without substantially } \\
\text { changing the content }\end{array}$ \\
\hline & Re write reform draft & $\begin{array}{l}\text { Re write an externally proposed reform draft } \\
\text { while substantially changing the content }\end{array}$ \\
\hline Resistance & Resist EU demands & $\begin{array}{l}\text { Resist specific EU demands with regard to } \\
\text { reform }\end{array}$ \\
\hline
\end{tabular}


Table 2. Continued.

\begin{tabular}{lll}
\hline Instrument & \multicolumn{1}{c}{ Means } & \multicolumn{1}{c}{ Description of means } \\
\hline Reject experts & $\begin{array}{c}\text { Reject the authority of external experts, } \\
\text { eventually refusing their participation in the } \\
\text { reform process } \\
\text { Reject the use of specific terminology } \\
\text { introduced by external actors } \\
\text { terminology } \\
\text { Reject draft law } \\
\text { Eecision makers reject a reform draft } \\
\text { elaborated with EU assistance } \\
\text { Attempt to limit the number of EU projects in } \\
\text { one institution or reform area } \\
\text { Develop own goals with regard to a policy } \\
\text { Develop reform strategies independent of EU } \\
\text { demands } \\
\text { Develop own goals } \\
\text { Develop own strategies } \\
\text { Provide own funding }\end{array}$ & $\begin{array}{l}\text { Organize funding from the state budget for own } \\
\text { reform projects }\end{array}$ \\
\hline
\end{tabular}

Source: Authors' compilation.

in Governance and Management" (SIGMA), a joint initiative of the Organization of Economic Cooperation and Development (OECD) and the European Union (EU) ${ }^{48}$ The main actor on the Croatian side during the phase of policy formulation was the MoA, the domestic institution responsible for drafting and implementing the reform at the level of ministers, state secretaries, and heads of division. The Croatian cabinet and parliament were also part of the decision-making process, and the Croatian Office of the Chief Negotiator discussed the GAPA in EU accession negotiations (see Figure 2).

\section{Agenda setting (2003)}

In the reform of the GAPA, the EU acted as the agenda-setter, demanding alignment of administrative regulations with European administrative principles. In

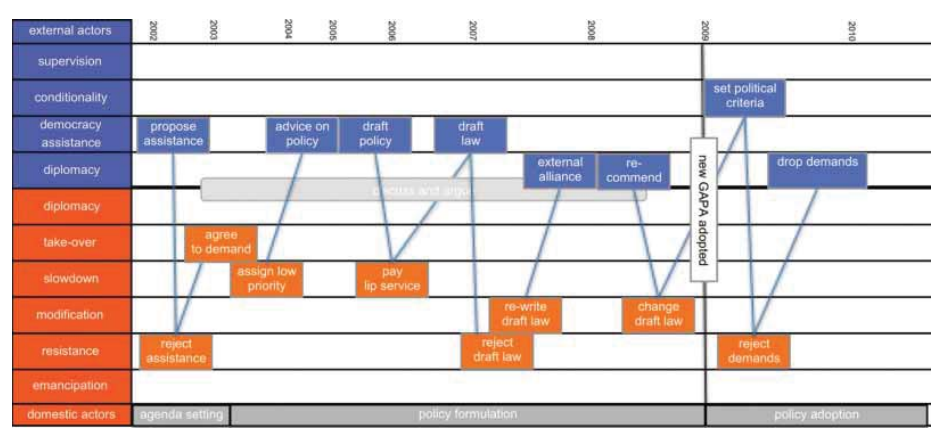

Figure 2. (Colour version available online). The external domestic interplay of the GAPA. Source: Authors' compilation.

Note: Blue $=$ external actors; orange $=$ domestic actors. 
2003, the European Commission offered financial assistance to reform the GAPA through the CARDS 2003 project. At first, reform demands were met with resistance by the Croatian government. It rejected the proposed assistance as it did not see a need for reform. Only after discussions did the Croatian government agree to EU demands and to the CARDS 2003 project, which was scheduled to begin in 2006.

Policy formulation phase 1: low interaction (2003-2005)

The first phase of policy formulation, from 2003-2005, was characterized by low levels of external-domestic interaction. External reform demands were met with slowdown by domestic actors. In 2004, the then state secretary of the MoA assigned low priority to the reform, establishing a working group that was never invited to meet. The following year, external actors reacted with democracy assistance to push the process forward. SIGMA offered assistance in the form of an expert who would advise on policy formulation by assessing possible amendments to the old GAPA. ${ }^{49}$

\section{Policy formulation phase 2: high interaction (2006-2008)}

The second phase of policy formulation, from 2006-2008, was characterized by high levels of interaction between external actors and the MoA. When the CARDS 2003 project started, the project team engaged very actively in advising on policy formulation, analysing reform options, and preparing policy papers and strategy papers on "Principles of Public Administration and Objectives on Administrative Procedures" to be adopted by the cabinet. The project team was dominated by radical reformers who proposed writing a completely new version of the GAPA that would cut the 600 procedures down to 200 . The Croatian side again used slowdown as an instrument to counter reform demands, adopting all pre-formulated documents but not engaging in drafting a new law based on these documents, thus paying lip service to the international advisors.

Policy formulation phase 3: escalation and antagonistic interaction (2008-2009)

As policy adoption approached, interactions between the EU project team, the EU delegation, and the Croatian government as a whole began to become more antagonistic. At the end of 2007, the EU project team presented its draft law for the new GAPA, which consisted of a completely new legal framework. The proposal was met with resistance, as it was considered to be far-reaching. Subsequently, the MoA used the instrument of modification, installing a new working group composed of MoA employees and moderate Croatian academics to re-write the draft law, again using the old GAPA as the point of departure and combining it with some of the innovations proposed by the project team. In response, the EU delegation resorted to more coercive means of diplomacy to exert pressure on the ministry. The 
delegation sought alliance with other external actors, asking SIGMA to issue recommendations on the results of the working group, with partial success. Some recommendations were included by the ministerial working group, but without alterations to the basic structure.

Policy adoption (2009)

In March 2009, the domestically prepared draft of the GAPA was adopted in parliament. In response, the EU delegation applied the instrument of conditionality to push for further changes. In the EU negotiations in October 2009, it was argued that the law did not meet EU soft political criteria with regard to EU best practices for administrations, and that EU accession might be endangered if no amendments were made. ${ }^{50}$ However, the MoA made it quite clear that it would not accept further changes to the new GAPA, arguing that they had "found their own solution" to integrate essential EU demands while maintaining a basic structure in line with established Croatian administrative traditions. ${ }^{51}$ After intensive discussions, the EU dropped its demands for changes to the new GAPA.

\section{Summary}

The reform of the GAPA can be judged as a mixed success. On the one hand, a new law was adopted and enacted. On the other hand, the adopted law differs to a great extent from the original proposal made by external consultants and leaves the basic structure of the old system intact. ${ }^{52}$ The Croatian government was thus satisfied with the result, whereas the European Union would favour further changes.

\section{External-domestic interplay with the CSSA}

The reform of the CSSA is regarded by the EU as the missing piece of a comprehensive reform of the legal basis of Croatia's professional civil service. The EU wishes to align and unify Croatia's wage system based on the principles of fiscal responsibility, equal pay for equal work, performance-based payments, and a competitive salary system. The wage system is criticized for being non-transparent, fragmentary, and without performance-based incentives. ${ }^{53}$ Payment is regulated in several separate laws for state civil servants, civil servants at local and regional levels, and the different public service groups. Special laws, decrees, and collective agreements lead to further differences between the wages of each group. ${ }^{54}$

The primary external actor involved in the CSSA was the EU delegation. World Bank, SIGMA, and British, Danish, and Swedish bilateral donor agencies also offered assistance. On the Croatian side, the MoA acted as the coordinator of the reform process. A well-institutionalized tripartite system, the so-called "social partnership", required the government (including the Ministry of Finance and all other line ministries) to negotiate with trade unions on this issue. ${ }^{55}$ Reaching an agreement proved difficult. The government, under pressure from the International 


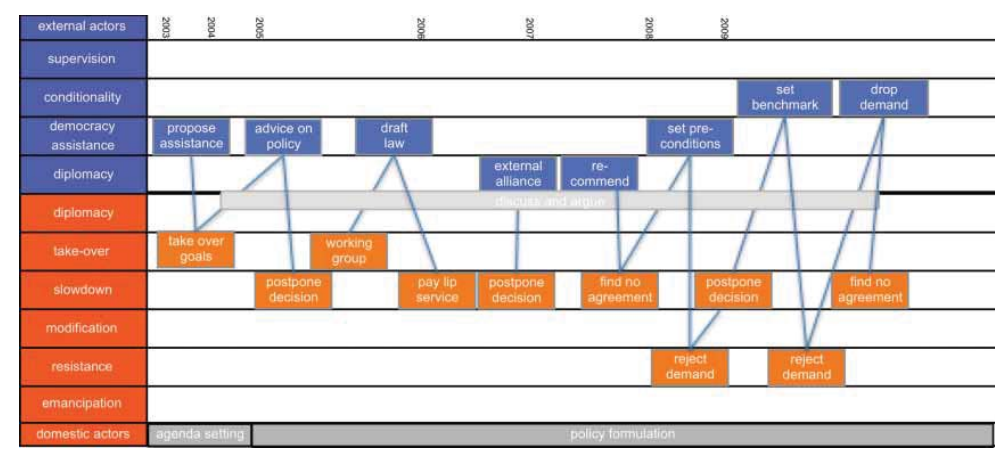

Figure 3. (Colour version available online). The external domestic interplay of the CSSA. Source: Authors' compilation.

Note: Blue $=$ external actors; orange $=$ domestic actors.

Monetary Fund (IMF), had pledged to cut public spending in $2009 .{ }^{56}$ Adjusting civil servant salaries through partial salary rise was thus opposed by the Ministry of Finance (backed by international organizations) while some trade unions opposed potential wage reductions or downsizing staff numbers (see Figure 3) ${ }^{57}$

\section{Agenda setting (2003)}

Again, the EU acted as the agenda-setter by demanding CSSA reform. The Croatian government reacted by taking over EU demands. A more transparent wage system was in its interests as well.

Policy formulation phase 1: democracy assistance and slowdown (2003-2008)

Between 2003 and 2008, the interactions between the Croatian government and international actors followed a repeating pattern: External actors provided policy advice via democracy assistance and Croatian decision-makers reacted with a general take-over of the EU goals, but then slowdown followed, postponing actual decisions. Several times the MoA installed working groups with all affected ministries and trade unions participating to negotiate a new CSSA. The EU, the World Bank, and SIGMA provided democracy assistance: external consultants analysed the Croatian system, made policy recommendations, and proposed draft laws to the working group. In 2005, the government postponed the decision on an externally drafted policy to the next year. ${ }^{58}$ The government took up negotiations within the tripartite system again in 2006 to unify the salary system. Again a draft law was produced with advice of external consultants. It was adopted by the government, but was not submitted to parliament in $2007 .{ }^{59}$ The government justified its slowdown strategy with the vague fiscal impact of that law; a dismissal in parliament should be avoided. The decision was postponed to take on discussions at a later stage. ${ }^{60}$ 
Policy formulation phase 2: conditionality (2008-2009)

Starting in 2008, after five years of democracy assistance, external actors reverted to the instruments of diplomacy and conditionality in an attempt to speed up the reform process. First, they used diplomacy, forming alliances with all involved donors and recommending the government speed up reform. ${ }^{61}$ As the government and trade unions were still unable to reach an agreement and thus continued to slow down the reform process, the EU resorted to the use of conditionality. In 2008, the EU made the adoption of the Salary Act a precondition for further financial grants to the MoA. ${ }^{62}$ The government responded with resistance to this EU demand because it anticipated that no agreement could be reached with trade unions at this point. In the end, the EU dropped the precondition. It provided financial assistance despite the lack of compliance. However, general take-over of EU demands on the part of domestic actors can be observed. In 2008, the government adopted another draft law with the help of external advice and through discussions within the social partnership. This draft was submitted to parliament in January 2009. This time, however, the parliament used slowdown techniques and postponed the decision due to doubts about financial sustainability. Severe protests and strikes by trade unions followed because they feared a new proposal would be less favourable to their demands.

\section{Policy formulation phase 3: conditionality and resistance (2009-?)}

In the autumn of 2009, in another attempt to heighten reform pressures, the EU once again resorted to the instrument of conditionality. It made the adoption of the CSSA a benchmark of Chapter 22 during accession negotiations. ${ }^{63}$ This demand was met with resistance from the Croatian government, who insisted on reaching an agreement with trade unions first; not to face severe strikes and social unrest. In the end the EU dropped its demand for a new CSSA as part of EU benchmarks. In spring 2011, another round of negotiations started; again without results. The proceedings of the working group were delayed until after the elections in November 2011.

Summary

Taking EU criteria as a benchmark, the reform of the CSSA cannot be evaluated as successful at this point, as no new law has been adopted to date. Finding a compromise between all the actors involved in the reform of the CSSA has proven to be very difficult, due to their widely diverging interests. However, this also means that domestic trade unions were able to influence the process and until now successfully prevented a reform in disfavour of civil servants' interests.

\section{Comparing the external-domestic interplay in the GAPA and the CSSA processes}

A comparison of the two externally requested reform initiatives reveals that both processes had a long phase of up to five years in the stage of policy formulation, 
in which external actors participated by providing advice and proposing reform drafts that were generally accepted by the Croatian government. When the point of policy adoption approached, two different developments could be observed, depending on whether strong veto players were involved in the reform or not.

In the case of the GAPA, resistance to the externally proposed reforms manifested itself after the end of the main democracy assistance project and shortly before the planned adoption of the new law. In a first step, the EU (in alliance with other international actors) used diplomacy to impede essential changes in the draft law, but significant modifications of the draft law were undertaken by the MoA and adopted by parliament nonetheless. In response, the EU resorted to the instrument of conditionality, threatening to deny EU accession, as the law did not meet EU soft political criteria. However, because the Croatian government was not prepared to include more radical changes in the GAPA, arguing that the adopted law did indeed incorporate the central demands made by the EU, conditionality was again unsuccessful.

In the case of the CSSA, where trade unions represented a strong third-party negotiation partner for the government, slowdown was the government's main instrument to manage external demands for reform. The adoption of the CSSA was postponed several times, as no agreement with trade unions could be reached. The EU reacted with the use of conditionality to push for adoption. However, the Croatian government resisted this demand, pointing to the need to continue negotiations with the third-party actors; the government ultimately succeeded, as the EU dropped its conditions.

In both reform initiatives, external actors first used democracy assistance to guide democratic reforms and later resorted to the use of (coercive) diplomacy and conditionality. Coercive means of diplomacy and conditionality were employed when the success of the reform attempts seemed to be in danger - for example, when domestic actors reverted to slowdown, modification, or resistance in response to demands for reform. However, the use of diplomacy and conditionality had only a limited effect on the course of reform. In the case of the CSSA, where third parties were involved in negotiations at the domestic level, the EU had to accept resistance and slowdown because of the government's obligation to reach a compromise with the trade unions before adoption. In the case of the GAPA, where no powerful third-party actor was part of the policy-making procedure, the EU was forced to accept resistance and modification when the Croatian government made it clear that it would not agree to more radical changes and was able to convince the commission that the adopted law would follow EU principles.

\section{Conclusions}

We have shown in this contribution that democracy promotion involves constant interactions between international democracy promoters and domestic actors in negotiating the content of democratic reforms. As this interaction has thus far not been conceptualized, we developed a new typology of the instruments and 
means used by external and domestic actors in their interplay during democracy promotion. A case study of PAR in Croatia served as the empirical basis for our investigation. Two concrete reform initiatives, the General Administrative Procedures Act (GAPA) and the Civil Service Salary Act (CSSA) were analysed. The analysis of these two reform projects illustrates first that democracy promotion entails a constant exchange of diplomatic means. Meeting, talking, and negotiating over the scope and scale of reforms continuously takes place during any reform process between external and domestic actors.

Second, we discovered that external-domestic interactions follow an escalation curve. In the early phase of policy formulation, interaction is less antagonistic. Democracy assistance on the external side and take-over on the domestic side are used in addition to diplomatic interactions. However, when the point of policy adoption approaches, the level of conflict in interaction increases. Here, two trends can be observed. If a strong third actor is involved on the domestic side, as was the case with the trade unions in the CSSA, slowdown and resistance are the main domestic instruments to avoid full compliance with external reform demands. The EU has reacted with the use of more coercive means of diplomacy and conditionality to enforce adoption of the CSSA, thus far without success. If no strong third actor is involved, another pattern emerges. Domestic actors use slowdown and modification to react to external reform demands. External actors use more coercive forms of diplomacy and conditionality when their reform attempts are perceived to be in jeopardy. In the end, the reform may have passed, but due to the strategy of modification employed by domestic actors, it can differ significantly to the original demands made by the EU.

Third, it should be noted that the association between external and domestic actors in democracy promotion is still characterized by an asymmetric relationship. Although donors continue to claim the importance of "local ownership" in transition, our investigation shows that demands for democratic reform and the initiative to place these issues on the agenda comes mostly from the external side. Domestic actors in Croatia had to adapt to external reform demands, learn how external actors organize policy-making, projects, and programmes, and then take over the implementation of basic liberal democratic principles in their political system. An alternative way of reorganizing the political system was not accepted by the external side. Furthermore, we found only limited signs of the emancipation of domestic actors; at least within PAR in Croatia, we found no evidence of incidents in which domestic actors took the lead in proposing a reform issue to external actors that became the object of a democracy promotion project.

Finally, we would nevertheless like to highlight that the external-domestic relationship is not completely a one-way street. Domestic actors employ a wide range of instruments with which they can alter external preferences and through which they can sometimes succeed in convincing external actors to accept modifications of drafted laws and to change reform objectives. The EU was ultimately obliged to drop certain aspects of its desired reforms, despite using all available instruments to avoid this outcome. 
In this article we demonstrated the analytical value of investigating the external-domestic interplay in democracy promotion. Based on our findings we hope that future research will study both sides of the interaction instead of focusing solely on the external side of democracy promotion, and that the proactive behaviour of domestic actors will be acknowledged, replacing the rather passive role previously assigned to domestic actors in post-conflict recovery and democratization with a more accurate and equitable representation.

\section{Acknowledgements}

We would like to thank Richard Batley, Timm Beichelt, Franziska Blomberg, Jan Hinrik Meyer Sahling, Gerald Schneider, the members of the research network "External Democ racy Promotion", the members of the Frankfurt Institute for Transformation Studies, the members of the Standing Group "Democracy Research" at the German Foundation for Pol itical Research, and two anonymous reviewers for their helpful comments on earlier versions of this manuscript. Special thanks to Claire Bacher for her kind and careful proofreading. Financial support from the Young Scholar Fund at the University of Konstanz is gratefully acknowledged.

\section{Notes}

1. Burnell, Democracy Assistance; Youngs, "Democracy and the Multinationals"; Schimmelfennig and Sedelmeier, The Europeanization; Vachudova, Europe Undivided.

2. For various typologies of democracy promotion instruments, see Burnell, Democracy Assistance; Zeeuw and Kumar, Promoting Democracy; Grimm, Erzwungene Demokratie.

3. Leininger, "Bringing the Outside In." The literature on European integration dis cusses domestic factors mitigating the "effectiveness" of external instruments in the form of adaption costs (Schimmelfennig and Sedelmeier, The Europeanization). However, domestic agency in the interaction with external actors is not explicitly discussed.

4. Leininger, "Bringing the Outside In."

5. Burton and Higley, "Elite Settlements"; Przeworski, Democracy and the Market, 51 99, 5660 .

6. Weiffen, Entstehungsbedingungen von Demokratien, 63 6; Burnell, Democracy Assistance; Carothers, Aiding Democracy Abroad; Youngs, "Democracy and the Mul tinationals"; Grimm and Leininger, "Not All Good Things Go Together."

7. Zeeuw and Kumar, Promoting Democracy; Amichai, Risse, McFaul, Promoting Democracy and the Rule of Law.

8. Burnell, Democracy Assistance; Zeeuw and Kumar, Promoting Democracy; Grimm, Erzwungene Demokratie; Schimmelfennig and Sedelmeier, The Europeanization.

9. Zürcher, Röhner, and Riese, "External Democracy Promotion”; Leininger, "“Bringing the Outside In."”

10. Schimmelfennig, and Sedelmeier, "Governance by Conditionality"; Grabbe, The EU's Transformative Power; Trauner, "Policy Conditionality."

11. Schimmelfennig and Sedelmeier, The Europeanization; Youngs, "Democracy Pro motion as External Governance?"; Toshkov, "Embracing European Law"; Börzel and Buzogány, "Governing EU Accession in Transition Countries"; Freyburg and Richter, "National Identity Matters". 
12. Börzel et al., "Obstinate and Inefficient"; Noutcheva, "Fake, Partial and Imposed Compliance"; Schimmelfennig and Sedelmeier, "Governance by Conditionality."

13. With the exception of Vachudova, Europe Undivided.

14. Keck and Sikkink, Activists Beyond Borders; Risse, Ropp, and Sikkink, Power of Human Rights.

15. Börzel et al., "Obstinate and Inefficient," 30; Fisher, Improving Compliance, 20.

16. Finnmore and Sikkink, "International Norm Dynamics"; Manners, "Normative Power Europe"; Acharya, "How Ideas Spread."

17. Carothers, Aiding Democracy Abroad, 137; Stedman, "Spoiler Problems in Peace Pro cesses"; Richmond, "Resistance and the Post Liberal Peace."

18. Groß and Grimm, "(State )Building Socio Economic Insecurity."

19. Flyvbjerg, "Five Misunderstandings about Case Study Research," 426.

20. Grimm, Erzwungene Demokratie, 349 63; Grimm and Mathis, "Stability First."

21. Flyvbjerg, "Five Misunderstandings about Case Study Research," 426.

22. Grandits, "The Power of "Armchair Politicians"; Zakosek, "Democratization, State Building and War"; European Commission, Croatia 2010 Progress Report, $7 \mathrm{ff}$.

23. Gerring, "What is a Case Study and What is it Good for?," 343.

24. Grimm and Mathis, "Stability First."

25. European Commission, Croatia 2011 Progress Report, 8.

26. SIGMA, European Principles for Public Administration, 814.

27. Grimm and Mathis, "Stability First."

28. The cut off point was chosen due to pragmatic reasons; however, our findings are still valid. The most recent EU Progress Report of 10 October 2012 yet admonishes the Croatian government that " $[\mathrm{t}]$ he legal framework on salaries, necessary to ensure merit based promotion and reward mechanisms and to attract and retain qualified per sonnel, still remains to be finalized" (European Commission, Comprehensive Moni toring Report on Croatia, 6).

29. The previous GAPA, dating from Yugoslav times, was regarded as too complex, as (over )regulating individual administrative steps, and as suffering from unclear procedures and limited chances for appeal (European Commission, Communication from the Commis sion, 8) while being prone to arbitrary decision making, legal uncertainty, and corruption (SIGMA, Croatia. Public Service and the Administrative Framework, 26).

30. Interview D5.

31. The GAPA received slightly more attention, with two EU grants (CARDS 2003 and IPA 2008), while the CSSA profited from a CARDS 2001 project grant and lesser assistance from external consultants from the World Bank and SIGMA (Interviews D5; E3; E4; E6).

32. Gerring, "What is a Case Study and What is it Good for?"; George and Bennett, Case Studies and Theory Development.

33. Meuser and Nagel, "Das Experteninterview." Document analysis refers to the annual EU Progress Reports, Pre Accession Economic Recovery Programmes, and project evaluations.

34. Ritchie, Lewis, and Elan, Designing and Selecting Samples, 56.

35. George and Bennett, Case Studies and Theory Development.

36. Schimmelfennig and Sedelmeier, The Europeanization; Lavenex and Schimmelfen nig, "EU Rules Beyond EU Borders."

37. Scharpf, Verwaltungswissenschaft als Teil der Politikwissenschaft.

38. Ibid., 169.

39. Anderson, Public Policymaking.

40. See Grimm, Erzwungene Demorkratie, for more details.

41. Berridge, Diplomacy: Theory \& Practice.

42. Burnell, Democracy Assistance, 4 5; Grimm and Mathis, "Stability First." 
43. Carothers, Aiding Democracy Abroad.

44. Schimmelfennig and Sedelmeier, "Governance by Conditionality," 662.

45. Grimm, Erzwungene Demokratie, 180231.

46. SIGMA, Croatia. Public Service and the Administrative Framework.

47. The Yugoslav GAPA from 1956 was amended in 1965, 1977, 1978, and 1986, but its main features remained similar, even to the old Yugoslav General Administrative Pro cedure Act of 1930; see Kopric, "Administrative Technology," 439.

48. German political party foundations supported administration reform already in 1991 1992, but with limited financial resources.

49. Interview D6; Republic of Croatia, 2004 Pre Accession Economic Recovery Programme.

50. Interview D2.

51. Interview D6.

52. Kopric, Novi Zakon; European Commission, Croatia 2011 Progress Report.

53. SIGMA, Croatia. Public Service and the Administrative Framework.

54. Ibid.

55. Samostalnu službu za socijalno partnerstvo [Independent Service for Social Partner ship] and Interview D1.

56. Republic of Croatia, 2009 Pre Accession Economic Recovery Programme.

57. To understand the strong opposition on behalf of different domestic actors one has to take into account two things. First, the average net earnings of a Croatian employee is 7679 kuna $(€ 1020)$ while the salary of state civil servants is calculated with a base rate of 5.108 (€679) (Državni Zavod Za Statistiku, Hravatska U Brojkama 2011, 11). Second, in 2011, Croatia's state budget amounted to $42 \%$ of gross domestic product (GDP) and the government spent $10.7 \%$ of GDP civil servants' salary (IMF, The Republic of Croatia, 29 and 31). Plus, the 37,400 Croatian state civil servants made up for $2.3 \%$ of the employed population, which is a relatively high percentage in regional comparison (ranging from 1.28\% to 5.5\%); see Cohen, "Administrative Development," 10). The problem of finding a solution suitable to everyone was also mentioned in interviews D1; D6; D7.

58. Republic of Croatia, 2005 Pre Accession Economic Recovery Programme, 76.

59. Republic of Croatia, 2006 Pre Accession Economic Recovery Programme, 66.

60. Interview E2.

61. Interview E3.

62. Interview E3.

63. Interview D4.

\section{Notes on contributors}

Lisa Groß is a PhD candidate in the Department of Politics and Public Administration, Uni versity of Konstanz. She specializes in post conflict peace building in the Western Balkans with a special focus on the transition in Kosovo.

Sonja Grimm is Senior Lecturer in the Department of Politics and Public Administration, University of Konstanz. She specializes in studies of transition to democracy in post conflict societies and has previously co edited special issues of Democratization on "War and Demo cratization: Legality, Legitimacy, and Effectiveness" (15, no. 3 (2008), with Wolfgang Merkel) and "Do All Good Things Go Together? Conflicting Objectives in Democracy Pro motion" (19, no. 3 (2012), with Julia Leininger and Tina Freyburg).

\section{Bibliography}

Acharya, A. "How Ideas Spread. Whose Norms Matter? Norm Localization and Institutional Change in Asian Regionalism.” International Organization 58, no. 2 (2004): 239275. 
Amichai, M., T. Risse, and M. A. McFaul, eds. Promoting Democracy and the Rule of Law: American and European Strategies. Venus Approaching Mars? The European Union's Approaches to Democracy Promotion. Houndmills: Palgrave Macmillan, 2009.

Anderson, J. E. Public Policymaking. New York: Praeger, 1975.

Berridge, G. R. Diplomacy: Theory \& Practice. Basingstoke: Palgrave, 2010.

Börzel, T., and A. Buzogány. "Governing EU Accession in Transition Countries. The Role of Non State Actors." Acta Politica 45, nos. 12 (2010): 158182.

Börzel, T., T. Hofmann, D. Panke, and C. Sprungk. "Obstinate and Inefficient. Why Member States Do Not Comply With European Law.” Comparative Political Studies 43, no. 11 (2010): 13631390.

Burnell, P., ed. Democracy Assistance. International Co operation for Democratization. London: Frank Cass. 2000.

Burton, M., and J. Higley. "Elite Settlements." American Sociological Review 52, no. 3 (1987): 295307.

Carothers, T. Aiding Democracy Abroad: The Learning Curve. Washington, DC: Brookings Institution Press, 1999.

Cohen, L. “Administrative Development in 'Low Intensity' Democracies. Governance, Rule of Law and Corruption in the Western Balkans." Simons Paper in Security and Development, Vancouver, 2010.

Državni Zavod Za Statistikun [Croatian Bureau for Statistics]. Hravatska U Brojkama 2011 [Croatia in Figures]. Zagreb: Croatian Bureau for Statistics, 2011.

European Commission. Communication from the Commission. A Strong European Neighbourhood Policy. COM(2007) 774 final. Brussels: European Commission, 2007.

European Commission. Croatia 2010 Progress Report. SEC(2010) 1326. Brussels: European Commission, 2010.

European Commission. Croatia 2011 Progress Report. SEC(2011) 1200 final. Brussels: European Commission, 2011.

European Commission. Comprehensive Monitoring Report on Croatia. SWD (2012) 338. Brussels: European Commission, 2012.

Finnmore, M., and K. Sikkink. "International Norm Dynamics and Political Change." International Organization 52, no. 4 (1998): 887917.

Fisher, R. Improving Compliance with International Law. Charlottesville: University Press of Virginia, 1981.

Flyvbjerg, B. "Five Misunderstandings about Case Study Research." Qualitative Inquiry 12, no. 2 (2006): 219245.

Freyburg, T., and S. Richter. "National Identity matters: The Limited Impact of EU Political Conditionality in the Western Balkans." Journal of European Public Policy 17, no. 2 (2010): 263281.

George, A., and A. Bennett. Case Studies and Theory Development in the Social Sciences. Cambridge: MIT Press, 2005.

Gerring, J. "What is a Case Study and What is it Good for?" American Political Science Review 98, no. 2 (2004): 341354.

Grabbe, H. The EU'S Transformative Power: Europeanization through Conditionality in Central and Eastern Europe. New York: Palgrave Macmillan, 2005.

Grandits, H. "The Power of 'Armchair Politicians': Ethnic Loyalty and Political Factionalism among Herzegovinian Croats." In The New Bosnian Mosaic: Identities, Memories and Moral Claims in a Post War Society, edited by X. Bougarel, E. Helms, and G. Duijzings, 101 122. Aldershot: Ashgate, 2007.

Groß, L., and S. Grimm. "(State )Building Socio Economic Insecurity: Understanding 'Local Resistance' in Croatian Administration Reform." Unpublished manuscript. Konstanz: University of Konstanz, 2012. 
Grimm, S. Erzwungene Demokratie: Politische Neuordnung nach militärischer Intervention unter externer Aufsicht [Democracy Imposed. Political Reorganisation after Military Intervention under External Oversight]. Baden Baden: Nomos, 2010.

Grimm, S., and J. Leininger. "Not All Good Things Go Together: Conflicting Objectives in Democracy Promotion." Democratization 19, no. 3 (2012): 391414.

Grimm, S., and O. L. Mathis. "Stability First, Development Second, Democracy Third: The European Union's Policy Towards Post Conflict Western Balkans, 1991 2010." Unpublished manuscript. Konstanz: University of Konstanz, 2012.

IMF. The Republic of Croatia. 2012 Article IV Consultation. Washington, DC: International Monetary Fund, 2012.

Keck, M., and K. Sikkink. Activists Beyond Borders. Advocacy Networks in International Politics. Ithaca, NY: Cornell University Press, 1998.

Koprić, I. "Novi Zakon o općem upravnom postupku tradicija ili modernizacija [New General Administrative Procedure Act Tradition or Modernisation]?" In Modernizacija općeg upravnog postupka i javne uprave u Hrvatskoj [Modernisation of general administrative procedure and public administration in Croatia], edited by I. Koprić and V. Đulabić, 21 52. Zagreb: Institut za javnu upravu and Društveno veleuči lište u Zagrebu, 2009.

Koprić, I. "Administrative Technology and General Administrative Procedure: Challenges and Changes in South Eastern Europe." Hrvatska Javna Uprava/Croatian Public Administration no. 1 (2011): 435454.

Lavenex, S., and F. Schimmelfennig. "EU Rules Beyond EU Borders. Theorizing External Governance in European Politics." Journal of European Public Policy 16, no. 6 (2009): 791812.

Leininger, J. "'Bringing the Outside In': Illustrations from Haiti and Mali for the Re Conceptualization of Democracy Promotion." Contemporary Politics 16, no. 1 (2010): 6380 .

Manners, I. "Normative Power Europe. A Contradiction in Terms?" Journal of Common Market Studies 40, no. 2 (2002): 235258.

Meuser, M., and U. Nagel. "Das Experteninterview Wissenssoziologische Voraussetzungen und methodische Durchführung [The expert interview research requisites and methodology]." In Handbuch Qualitative Forschungsmethoden in der Erziehungswissenschaft [Handbook Qualitative Research Methods in Educational Science], edited by B. Friebertshäuser, A. Langer, and A. Prengel, 481 491. Basel/ Weinheim: Juventa, 1997.

Noutcheva, G. "Fake, Partial and Imposed Compliance: The Limits of the EU's Normative Power in the Western Balkans." Journal of European Public Policy 16, no. 7 (2009): 10651084

Przeworski, A. Democracy and the Market: Political and Economic Reforms in Eastern Europe and Latin America. Cambridge: Cambridge University Press, 1991.

Republic of Croatia. 2004 Pre Accession Economic Recovery Programme. Zagreb, 2005.

Republic of Croatia. 2005 Pre Accession Economic Recovery Programme. Zagreb, 2006.

Republic of Croatia. 2006 Pre Accession Economic Recovery Programme. Zagreb, 2007.

Republic of Croatia. 2009 Pre Accession Economic Recovery Programme. Zagreb, 2010.

Richmond, O. "Resistance and the Post Liberal Peace." Millenium Journal of International Studies 38, no. 3 (2010): 665692.

Risse, T., S. Ropp, and K. Sikkink. The Power of Human Rights. International Norms and Domestic Change. Cambridge: Cambridge University Press, 1999.

Ritchie, J., J. Lewis, and G. Elan. Designing and Selecting Samples. Qualitative Research Practice. A Guide for Social Science Research Students, 77 108. London: Sage, 2003.

Samostalnu službu za socijalno partnerstvo [Independent Service for Social Partnership], 2011. Accessed December 12, 2012. http://www.socijalno partnerstvo.hr. 
Scharpf, F. W. "Verwaltungswissenschaft als Teil der Politikwissenschaft. Planung als poli tischer Prozess [Administrative science as political science. Planning as political process]." In Aufsätze zur Theorie der planenden Demokratie [Essays on a theory of a planning democracy], edited by F. W. Scharpf, 9 32. Frankfurt a.M.: Suhrkamp, 1973.

Schimmelfennig, F., and U. Sedelmeier. "Governance by Conditionality: EU Rule Transfer to the Candidate Countries of Central and Eastern Europe." Journal of European Public Policy 11, no. 4 (2004): 661679.

Schimmelfennig, F., and U. Sedelmeier, eds. The Europeanization of Central and Eastern Europe. Ithaca, NY: Cornell University Press, 2005.

SIGMA. European Principles for Public Administration. SIGMA Papers No. 27. Paris: OECD Publishing, 1999.

SIGMA. Croatia. Public Service and the Administrative Framework. Assessment June 2007. Paris: OECD Publishing, 2007.

Stedman, S. J. "Spoiler Problems in Peace Processes." International Security 22, no. 2 (1997): 553.

Toshkov, D. "Embracing European Law: Compliance with EU Directives in Central and Eastern Europe.” European Union Politics 9, no. 3 (2008): 379402.

Trauner, F. "From Membership Conditionality to Policy Conditionality: EU External Governance in South Eastern Europe." Journal of European Public Policy 16, no. 5 (2009): 774790.

Vachudova, M. A. Europe Undivided: Democracy, Leverage, and Integration since 1989. Oxford: Oxford University Press, 2005.

Weiffen, B. Entstehungsbedingungen von Demokratien: Interne und externe Einflüsse in Vergleich [Conditions of Democracy: Internal and External Factors in Comparison]. Baden Baden: Nomos, 2009.

Youngs, R. "Democracy and the Multinationals." Democratization 11, no. 1 (2004): 127147.

Youngs, R. "Democracy Promotion as External Governance?" Journal of European Public Policy 16, no. 6 (2009): 895915.

Zakosek, N. "Democratization, State Building and War: The Cases of Serbia and Croatia." Democratization 15, no. 3 (2008): 588610.

Zeeuw, J. D., and K. Kumar, eds. Promoting Democracy in Postconflict Societies. Boulder, CO: Lynne Rienner, 2006.

Zürcher, C., N. Röhner, and S. Riese. "External Democracy Promotion in Post Conflict Zones. Evidence from Case Studies." Taiwan Journal of Democracy 5, no. 1 (2009): 241259. 